\title{
Pengaruh Iklim Psikologis Terhadap Keinginan Karyawan \\ Untuk Keluar Perusahaan Melalui Kepuasan Kerja \\ (Studi pada PT. Hervitama Indonesia)
}

\author{
Esa Ayu Sukma Dewi * \\ Fakultas Ekonomi, Universitas Negeri Surabaya, Indonesia \\ Anang Kistyanto \\ Fakultas Ekonomi, Universitas Negeri Surabaya, Indonesia
}

\begin{abstract}
PT. Hervitama Indonesia which is engaged in providing instrumentation goods and installation services has a work area for electrical installation, instrumentation, construction, interior and calibration works. Service provider in the field of electrical installation by PT. Hervitama Indonesia includes the strong and weak currents installation. The purpose of this study is to test and analyze the influence of psychological climate on the desires of employees to leave the company through job satisfaction for employees of PT. Hervitama Indonesia. This research is a causality study with a quantitative approach. The sampling technique uses saturated samples with a total of 50 respondents to employees of PT. Hervitama Indonesia. The statistical analysis used in this study was PLS with the help of smartPLS 3.0 software. The results of this study explain that the psychological climate has a negative and significant effect on the desire of employees to leave the company. Psychological climate has a positive and significant effect on job satisfaction. Job satisfaction does not affect the desire of employees to leave the company. The research implications that can be applied to companies, namely the need for leaders to improve the quality and quantity in terms of support provided to employees or subordinates can be done by way of guidance to employees in doing good work. For example, holding back inter-unit counseling that discusses the constraints of work in the field related to work.
\end{abstract}

JEL : O15, J63, D91

Keywords : Psychological Climate, Job Satisfaction, Turnover Intention

\section{PENDAHULUAN}

Era milenial sekarang ini, interior hunian banyak bergeser, bukan sekedar memenuhi kebutuhan fisik, tetapi juga memenuhi kebutuhan hati untuk keindahan hunian. Seiring dengan peningkatan kebutuhan akan hunian itulah yang menjadikan potensi bisnis desain dan interior

*Email : esadewi@mhs.unesa.ac.id

Received : 11-07-2019, Accepted : 24-07-2019, Published : 29-08-2019

P-ISSN : 2087-9954, E-ISSN : 2550-0066. DOI : http://dx.doi.org/10.26418/jebik.v8i2.34185 
terus meningkat (Mansur, 2018). Di Jawa Timur, permintaan jasa desain interior setiap tahunnya mengalami pertumbuhan yang cukup signifikan. Hal itu disampaikan oleh Ketua Himpunan Desainer Interior Indonesia (HDII) Jawa Timur, Niken Rarasrini menyampaikan bahwa pertumbuhan itu sejalan dengan pertumbuhan properti yang terus naik tiap tahunnya. Selain itu, masyarakat di Jawa Timur sekarang ini juga sudah banyak yang menyadari akan pentingnya desain interior bagi tempat tinggalnya (Rachmawati, 2018).

Salah satu perusahaan di Jawa Timur yang bergerak dalam bidang jasa desain interior adalah PT. Hervitama Indonesia. Perusahaan ini didirikan dan beroperasi sejak Agustus 2010. Perusahaan ini memiliki komitmen untuk memberikan yang terbaik dalam mutu, keselamatan, kesehatan kerja dan lingkungan. Sebagai upaya pengembangan perusahaan agar mampu bersaing dengan perusahaan lainnya, perlunya pemanfaatan potensi sumber daya yang ada. Oleh karena itu, karyawan berusaha diberikan bekal kemampuan keterampilan. Karena apabila karyawan berjiwa terampil dan handal akan mengembangkan Sumber Daya Manusia (SDM) perusahaan (Mathis \& Jackson, 2011). Seperti yang diutarakan oleh Lestari (2015) karyawan merupakan aset utama perusahaan yang menjadi perencana dan pelaku yang aktif setiap aktivitas yang dilakukan didalam organisasi. Oleh karena itu, cara untuk mempertahankan karyawan yang berkompeten bagi perusahaan merupakan suatu pertimbangan yang utama. Kenyataannya saat ini, dampak adanya perubahan dari perusahaan terhadap karyawan atau Sumber Daya Manusia (SDM) cenderung negatif. Salah satu permasalahan yang sering muncul pada Sumber Daya Manusia (SDM) yaitu: keinginan karyawan untuk keluar perusahaan. Seiring dengan pertumbuhan ekonomi yang semakin pesat, hal tersebut memicu peningkatan terhadap tingkat keinginan karyawan untuk keluar dari perusahaan dengan berbagai alasan (Javed, Yasir, Khan, \& Aamir, 2014) dan (Radjasa, 2015).

Banyak faktor yang membuat karyawan keluar dari perusahaan salah satunya yaitu faktor eksternal lingkungan kerjanya (Wahyuni, Zaika, \& Anwar, 2014). Faktor eksternal juga bisa karena adanya iklim perusahaan yang berdampak pada karyawannya. Iklim psikologis didefinisikan sebagai kemampuan individu dari peristiwa yang terjadi, dimana hal tersebut terjadi antara keadaan psikologis lingkungan terhadap individu (James \& Sells, 1981). Iklim psikologis sebagai penilaian kognitif terhadap lingkungan yang dianggap oleh individu dalam hal makna dan nilai pribadinya (Isaksen \& Lauer, 1999). Keinginan karyawan untuk keluar perusahaan bisanya diukur menggunakan indikator dari Swift dan Campbell (2016) yaitu: dukungan, otonomi, pengakuan, kohesi, inovasi, dan tekanan. Menurut Karanika-Murray, et al., (2017) dan Karanika-Murray dan Michaelides (2015) menggunakan tingkat kebebasan bertindak di tempat kerja, tingkat ketersediaan sumber daya yang mendukung pemenuhan persyaratan pekerjaan, dan sejauh mana konteks sosial memupuk hubungan yang bermakna di tempat kerja. Dan menurut Jones dan Jamest (1979); James dan Sells (1981) menggunakan karakteristik pekerjaan (misalnya: otonomi, tantangan, dan kepentingan), karakteristik peran (misalnya: ambiguitas, konflik, dan kelebihan beban), karakteristik kepemimpinan (misalnya: penekanan tujuan, dukungan, dan pengaruh keatas), karakteristik kelompok kerja dan lingkungan sosial (misalnya: kerjasama, kehangatan, dan kebanggan), dan atribut organisasi dan subsistem (misalnya: inovasi, kesadaran manajemen, dan keterbukaan informasi).

Penelitian tentang iklim psikologis terhadap keinginan karyawan untuk keluar perusahaan pernah dilakukan oleh beberapa peneliti salah satunya yaitu dari Garner dan Hunter (2013) dimana penelitian menjelaskan bahwa iklim psikologis mempunyai pengaruh negatif pada 
keinginan karyawan untuk keluar perusahaan artinya apabila iklim psikologi bagus maka keinginan keluar dari perusahaan menurun. Penelitian Munyaka (2012) menjelaskan bahwa iklim psikologis tidak mempengaruhi keinginan karyawan untuk keluar perusahaan. Tetapi hasil penelitian berbeda dilakukan oleh Gim, et al., (2015) yang menyatakan bahwa iklim psikologis kompetitif adalah stressor di tempat kerja yang secara positif terkait dengan keinginan karyawan berpindah. Dimana dalam perspektif praktis penelitian ini menyoroti dalam menetapkan kebijakan yang dapat menciptakan iklim psikologis kompetitif di tempat kerja bukan suatu hal yang baik untuk organisasi karena hal tersebut memotivasi karyawan untuk meninggalkan organisasi. Melalui hasil wawancara dengan owner PT. Hervitama Indonesia, mengatakan bahwa karyawan banyak yang keluar dari perusahaan ini tetapi pihak perusahaan juga tidak mengetahui alasan karyawan tersebut keluar dari perusahaan. Dilihat dari segi gaji, semua karyawan mendapatkan gaji sudah diatas UMK, tugas sudah sesuai dengan keahlian masing-masing tetapi intensitas karyawan keluar perusahaan masih tinggi. Hal itu sejalan melalui hasil wawancara dengan salah satu karyawan di PT. Hervitama Indonesia mengatakan jika hubungan antara rekan kerja di perusahaan sangat baik. Mereka sering jalan-jalan jika jam kerja kantor sudah selesai, makan bersama di kantor, adanya budaya sholat jamaah bersama karyawan ataupun atasan, jadi saat istirahat membaur menjadi satu sehingga dapat dikatakan kebersamaan di lingkungan perusahaan terjalin sangat baik.

Selain keinginan karyawan untuk keluar perusahaan dipengaruhi oleh iklim psikologis, ada faktor lain yang dapat memepengaruhinya salah satunya yaitu kepuasan kerja (Nayaputera, 2011). Kepuasan kerja yaitu hasil dari presepsi karyawan mengenai seberapa baik pekerjaan mereka dan yang dinilai penting Luthans (2005) sehingga kepuasan kerja sebagai suatu perasaan yang berhubungan dengan pekerjaan melibatkan aspek-aspek seperti: gaji atau upah yang diterima, kesempatan pengembangan karir, hubungan dengan pegawai lainnya, penempatan kerja, mutu pengawasan. Perasaan yang berhubungan dengan dirinya, antara lain: umur, kemampuan, kondisi kesehatan, dan pendidikan (Mangkunegara, 2011). Penelitian yang dilakukan oleh Huang, et al., (2016) dan Nafiudin (2015) menyatakan bahwa hubungan antara kepuasan kerja dengan keinginan karyawan untuk keluar perusahaan adalah negatif. Artinya jika seorang karyawan merasa dirinya puas bekerja di perusahaan tersebut maka mereka keinginan karyawan untuk meninggalkan perusahaan akan rendah. Penelitian oleh Aslani dan Fayyazi (2015) mengemukakan bahwa hubungan antara kepuasan kerja dengan keinginan karyawan untuk keluar perusahaan berhubungan negatif. Kompensasi dari segi distribusi maupun prosedural dapat mempengaruhi kepuasaan dan kinerja Sumber Daya Manusia (SDM) (Soeselo, 2017). Jika karyawan puas terhadap perusahaan maka keinginan karyawan untuk keluar perusahaan akan sedikit.

Penelitian dengan hasil berbeda oleh Witasari (2009) mengemukakan bahwa hubungan antara kepuasan kerja dengan keinginan karyawan untuk keluar perusahaan berhubungan negatif tidak signifikan. Karyawan Novotel Semarang menyadari bahwa saat ini untuk mencari pekerjaan yang sesuai dengan pekerjaan atau harapan dan latar belakang pendidikan yang sesuai tidaklah mudah, sehingga sekalipun karyawan merasa tidak puas dengan pekerjaannya tidak langsung membuat mereka memutuskan untuk mengundurkan diri. Wawancara yang dilakukan penulis di PT. Hervitama Indonesia kepada owner perusahaan yaitu, bahwa hal yang terjadi di perusahaan menunjukkan realita bahwa karyawan merasa puas dengan keadaan lingkungan internal perusahaan. Salah satunya dilihat dari segi penggajian, semua karyawan sudah 
mendapatkan gaji sesuai dengan UMK yang berlaku di Kabupaten Sidoarjo. Tetapi karyawan yang keluar perusahaan juga terjadi sangat tinggi.

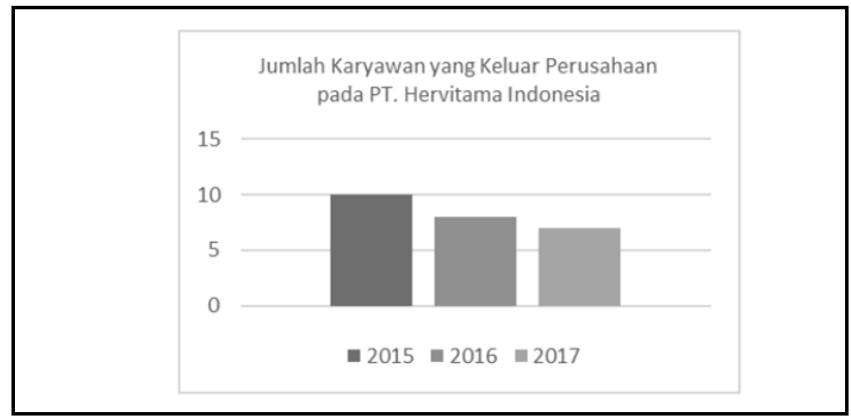

Sumber: Data Internal PT. Hervitama Indonesia, (2017)

\section{Gambar 1. Jumlah Karyawan yang Keluar Perusahaan pada PT. Hervitama Indonesia Tahun 2015-2017}

Dapat dilihat pada Gambar 1 bahwa data perusahaan menunjukkan karyawan yang keluar dari perusahaan pada tahun 2015-2017 cukup banyak. Dimana pada tahun 20115 terdapat 10 karyawan yang keluar perusahaan, pada tahun 2016 sudah mulai menurun dan terakhir pada angka 7 karyawan yang keluar perusahaan, dan data terakhir perusahaan pada tahun 2017 terdapat 7 karyawan yang keluar perusahaan.

Iklim psikologis juga mampu mempengaruhi kepuasan kerja yaitu, seperti penelitian yang dilakukan oleh Karanika-Murray, et al., (2017); Yee, et al., (2014); Mianto, et al., (2018) menyatakan bahwa iklim psikologis dan kepuasan kerja berpengaruh positif. Sehingga hal yang terjadi yaitu, jika iklim psikologis yang dirasakan tinggi maka kepuasan kerja yang dirasakan juga akan tinggi. Penelitian Carless (2004) yang dilakukan di Australia dengan membangikan kuesioner kepada 280 karyawan layanan pelanggan yang bekerja di bagian administrasi dan dua organisasi di keuangan swasta dan satu organisasi publik yang berada di Australia. Didapatkan sampel sebanyak 174 responden. Dengan hasil bahwa hubungan iklim psikologis dan kepuasan kerja yang dimediasi oleh pemberdayaan psikologis menghasilkan hasil non signifikan.

\section{KAJIAN LITERATUR}

Penelitian sebelumnya mengindikasikan bahwa keinginan karyawan untuk keluar perusahaan dipengaruhi oleh iklim psikologis melalui kepuasan kerja. Menurut Schneider dan Snyder (1975) dalam Madera, et al., (2016) iklim psikologis secara luas diambil untuk mengacu pada presepsi orang dalam memiliki organisasi kerja mereka. Iklim psikologis dapat merujuk kepada karyawan dan persepsi organisasi secara umum atau aspek organisasi, khususnya kebijakan, praktik, dan prosedur atau perilaku yang dihargai, didukung atau diharapkan James, et al., (2008). Sehingga ketika individu merasa lingkungan tempat kerja mereka positif, maka mereka lebih cenderung untuk berinvestasi lebih banyak usaha dan menghasilkan hasil yang lebih positif. Pada intinya efektifitas iklim secara positif mempengaruhi hasil karyawan yang bergantung pada kesesuaian dan spesifikasi iklim.

Menurut Handoko (1998) dalam Andini (2006) menyebutkan bahwa kepuasan kerja merupakan keadaan emosional yang menyenangkan atau tidak menyenangkan dimana para 
karyawan memandang pekerjaan mereka. Kepuasan kerja merupakan cermin perasaan seseorang terhadap pekerjaannya. Luthans (2006) dalam bukunya Organizational Behavior mengutip pendapat Locke bahwa kepuasan kerja merupakan keadaan emosional yang positif dari seseorang yang ditimbulkan dari penghargaan atau suatu pekerjaan yang telah dilakukannya. Dikatakan lebih lanjut bahwa kepuasa kerja merupakan hasil dari prestasi seseorang sampai seberapa baik pekerjaannya menyediakan sesuatu yang berguna baginya. Robbins (2001) mendefinisikan kepuasan kerja adalah suatu sikap umum seorang individu terhadap pekerjaannya, selisih antara banyaknya ganjaran yang diterima seorang pekerja dan banyaknya yang mereka yakini seharusnya diterima. Menurut Mathis \& Jackson (2001) keinginan karyawan untuk keluar perusahaan adalah kondisi dimana karyawan meninggalkan organisasi dan ingin segera dihentikan. Hal ini merupakan salah satu kerugian terbesar yang akan dialami perusahaan ketika banyak karyawannya, apalagi karyawan yang keluar adalah karyawan yang berpotensi. Menurut Oluwafemi (2013) bahwa keinginan karyawan untuk keluar perusahaan merupakan konsep yang dapat digunakan untuk memprediksi perilaku keinginan karyawan untuk keluar perusahaan sehingga probabilitas munculnya keinginan karyawan untuk keluar perusahaan dapat diketahui.

\subsection{Pengaruh Iklim Psikologis terhadap Keinginan Karyawan untuk Keluar dari Perusahaan}

Menurut Gim, et al., (2015) diperoleh hasil bahwa iklim psikologis berpengaruh positif dengan keinginan karyawan untuk keluar perusahaan dan berhubungan negatif dengan komitmen afektif. dan juga terungkap bahwa komitmen afektif berhubungan negatif dengan keinginan karyawan untuk keluar perusahaan dan itu memediasi hubungan antara iklim psikologis kompetitif dengan keinginan karyawan untuk keluar perusahaan. Menurut Gyensare, et al., (2017) mengemukakan bahwa hasil yang ditunjukkan menunjukkan bahwa hubungan iklim psikologis dan keinginan karyawan untuk keluar perusahaan berpengaruh negatif. Sehingga, jika iklim psikologis positif maka keinginan karyawan untuk keluar perusahaan juga akan rendah dan begitupula sebaliknya.

Menurut Munyaka, et al., (2017) menyatakan bahwa iklim psikologis tidak dapat memprediksi keinginan karyawan untuk keluar dari perusahaan. Sehingga dapat diartikan bahwa jika iklim psikologis baik maka tidak dapat dikatakan bahwa keinginan karyawan untuk keluar perusahaan rendah dan begiru pula sebaliknya jika iklim psikologis dirasa buruk maka belum tentu juga keinginan karyawan untuk keluar perusahaan juga tinggi. Menurut Garner dan Hunter (2013) dengan hasil negatif signifikan dimana hal tersebut jika iklim psikologis yang dirasakan tinggi maka keinginan karyawan untuk keluar dari perusahaan akan rendah, apabila iklim yang dirasakan buruk maka keinginan karyawan untuk keluar perusahaan juga akan tinggi.

$\mathbf{H}_{1}$ : iklim psikologis berpengaruh negatif terhadap keinginan karyawan untuk keluar perusahaan

\subsection{Pengaruh Iklim Psikologis terhadap Kepuasan Kerja}

Menurut Karanika-Murray, et al., (2017) menyatakan bahwa iklim psikologis secara luas mengacu pada presepsi orang yang memiliki organisasi kerja mereka. Ketika individu merasa lingkungan tempat kerja mereka positif, maka mereka akan lebih cenderung untuk berinvestasi lebih banyak usaha dan menghasilkan hasil yang lebih positif. Jadi iklim psikologis dapat menjadi faktor kontekstual yang signifikan yang mempengaruhi karakteristik pekerjaan cara mempengaruhi kepuasan kerja. Iklim psikologis tidak hanya berdampak pada kepuasan kerja 
tetapi juga membentuk bagaimana persepsi pekerjaan itu sendiri dapat mempengaruhi kepuasan kerja. Menurut Mianto, et al., (2018) menjelaskan bahwa terdapat pengaruh dan signifikan antara variabel iklim psikologis melalui kepuasan kerja terhadap kinerja karyawan. Dengan arti bahwa variabel kepuasan kerja memoderasi pengaruh tidak langung antara iklim psiokologis terhadap kinerja karyawan. Hal ini berarti bahwa setiap peningkatan iklim psikologis akan meningkatkan kepuasan kerja dan juga akan meningkatkan kinerja pegawai.

Menurut Hakim \& Surjanti (2018) menunjukkan hasil bahwa iklim psikologis terhadap kinerja karyawan melalui kepuasan kerja memberikan dampak positif dan signifikan. Dimana kinerja karyawan meningkat karena menyesuaikan perilaku dengan iklim yang ada di perusahaan. Namun, dalam penelitian ini kepuasan kerja tidak dapat menjadi acuan tinggi rendahnya kinerja karyawan, sehingga tinggi rendahnya kinerja karyawan tidak akan berdampak terhadap kepuasan kerja. Menurut Tenaya \& Suwandana (2019) menyatakan bahwa iklim psikologis memiliki pengaruh positif dan signifikan terhadap kepuasan kerja. Artinya iklim psikologis yang baik akan menigkatkan tingkat kepuasan kerja karyawan di perusahaan. Semakin baik iklim psikologis di perusahaan, maka karyawan akan semakin puas terhadap pekerjaan maupun perusahaan tersebut.

Menurut Maranggi \& Subudi (2018) hasil penelitian ditemukan bahwa iklim psikologis berpengaruh positif dan signifikan terhadap kepuasan kerja. Artinya, apabila perusahaan mampu menciptakan iklim psikologis yang baik maka kepuasan kerja karyawan dalam melaksanakan pekerjaannya akan semakin baik pula.

$\mathbf{H}_{2}$ : iklim psikologis berpengaruh positif terhadap kepuasan kerja

\subsection{Pengaruh Kepuasan Kerja terhadap Keinginan Karyawan untuk Keluar dari Perusahaan}

Dalam penelitian Huang, et al., (2016) dapat menunjukkan hasil bahwa baik kepuasan kerja kognitif memiliki efek negatif yang lebih kuat pada keinginan karyawan untuk keluar perusahaan daripada kepuasan kerja afektif. Dan kepuasan kerja afektif maupun kepuasan kerja kognitif bergantung pada faktor-faktor yang terkait dengan kemudahan pergerakan. Kepuasan kerja kognitif lebih efektif ketika alternatif pekerjaan rendah dan dukungan kebijakan tinggi, sedangkan kepuasan kerja afektif mengarah ke pergantian yang lebih rendah ketika alternatif pekerjaan tinggi dan dukungan kebijakan rendah. Teori yang diungkapkan Hanafiah (2014) keinginan untuk berpindah dari tempat kerja ke tempat kerja lainnya, dipengaruhi aspek kepuasan kerja yang meliputi kepuasan atas supervisi yang diterima, kepuasan upah dan promosi, kepuasan dengan rekan kerja, dan kepuasan akan pekerjaan. Tidak adanya kepuasan kerja yang dimiliki oleh karyawan akan mempengaruhi kondisi karyawan tersebut dan akibatnya cenderung meningkatkan keinginan karyawan untuk keluar dari pekerjaannya.

Menurut Tnay, et al., (2013) penelitian ini menunjukkan bahwa kepuasan kerja berhubungan positif signifikan terhadap keinginan karaywan untuk keluar perusahaan. Dengan hal tersebut, jika kepuasan dirasa rendah maka keinginan karayawan untuk keluar perusahaan tinggi, dan bila kepuasan kerja yang dirasakan melebihi apa yang diharapkan maka keinginan karyawan untuk keluar perusahaan akan rendah. Menurut Witasari (2009) bahwa hasil pengujian yang dilakukan dalam penelitian ini terhadap variabel kepuasan kerja dan keinginan karyawan untuk keluar perusahaan menunjukkan bahwa kepuasan kerja memiliki pengaruh negatif tidak signifikan terhadap keinginan karyawan untuk keluar perusahaan. Hal tersebut membuktikan 
bahwa masih ada karyawan yang puas terhadap pekerjaannya, tetap berkeinginan untuk meninggalkan pekerjaannya sebagai karyawan.

Hasil indepth interview yang dilakukan terhadap karyawan menunjukkan bahwa karyawan yang puas bekerja tidak pernah menutup adanya kemungkinan untuk meninggalkan pekerjaan dan mencari pekerjaan di tempat lain. Sebaliknya, karyawan yang tidak puas bekerja di perusahaan tidak langsung memiliki niat atau keinginan untuk keluar dari pekerjaannya. Menurut Suifan, et al., (2017) hubungan variabel antara keadilan organisasi dan keinginan karyawan untuk keluar perusahaan yang dimediasi oleh kepuasan kerja memiliki hubungan yang negatif signifikan, sehingga temuan menyimpulkan bahwa penerimaan variabel kepuasan kerja yang berperan sebagai mediasi. Meskipun demikian, kepuasan kerja sepenuhnya dimediasi hubungan antara keadilan organisasi dan keinginan karyawan untuk keluar perusahaan.

Menurut Lambert, et al., (2001) hubungan antara lingkungan kerja dan keinginan karyawan untuk keluar perusahaan yang dimediasi oleh kepuasan kerja memiliki hubungan yang negatif signifikan sehingga perusahaan harus fokus pada lingkungan kerja untuk meningkatkan kepuasan pekerja dan dengan hal tersebut maka keinginan karyawan untuk keluar perusahaan akan rendah.

H3: kepuasan kerja berpengaruh negatif terhadap keinginan karyawan untuk keluar perusahaan

H4: kepuasan kerja memediasi iklim psikologis terhadap keinginan karyawan untuk keluar perusahaan

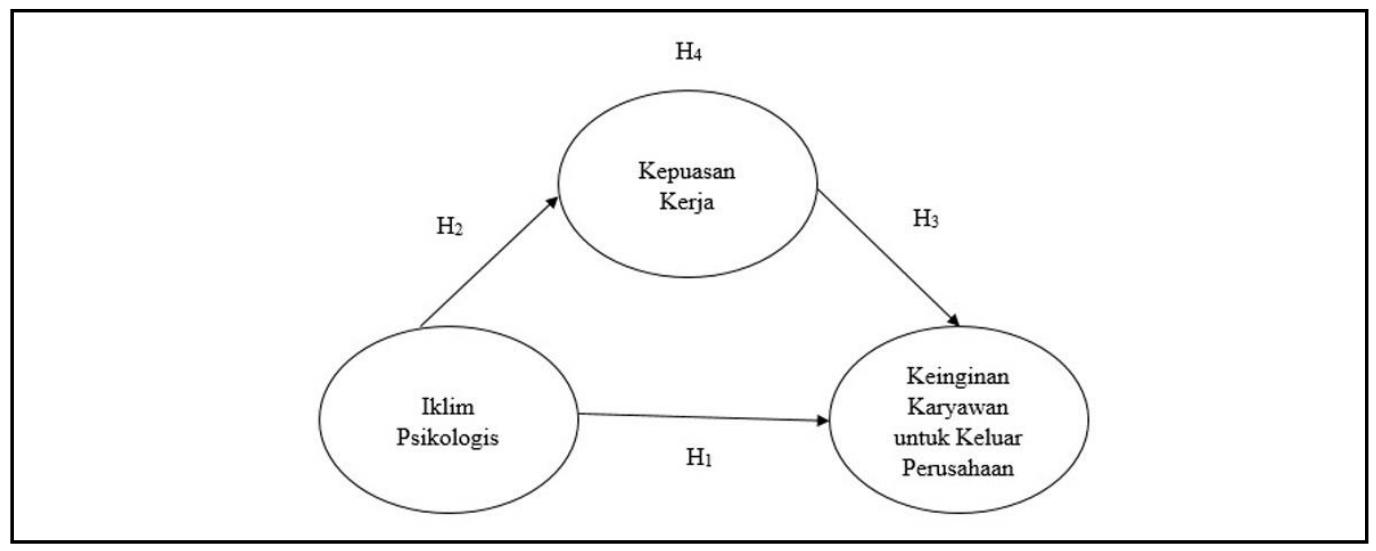

Gambar 2. Model Penelitian

\section{METODA PENELITIAN}

Penelitian yang dilakukan ini menggunakan metode penelitian kuantitatif. Lokasi penelitian ini dilaksanakan di PT. Hervitama Indonesia. Populasi penelitian ini menggunakan seluruh karyawan PT. Hervitama Indonesia yang berjumlah 50 karyawan. Menggunakan teknik sampling jenuh, sehingga total sampel yang diambil adalah seluruh populasi yaitu 50 karyawan. Teknik Pengumpulan data pada penelitian ini mengguakan teknik observasi, wawancara secara tidak terstruktur yang dilakukan peneliti dengan beberapa karyawan PT. Hervitama Indonesia, dan penyebaran kuesioner. 
Instrumen yang digunakan dalam penelitian ini adalah kuesioner yang disebarkan kepada karyawan PT. Hervitama Indonesia dengan skala pengukuran menggunakan skala likert range atau rentang skalanya adalah mulai dari angka 1 (sangat tidak setuju) sampai dengan nilai terbesar yaitu skala 5 (sangat setuju). Sumber data menggunakan data primer dan sekunder melalui website atau studi literatur lainnya.

\subsection{Partial Least Square (PLS)}

Langkah-langkah PLS menurut Ghozali (2008) yaitu: merancang model struktural atau inner model, merancang model pengukuran atau outer model, mengkontruksi diagram jalur, pendugaan parameter (estimasi) dalam PLS adalah metode kuadrat terkecil (least square methods), goodness of fit, pengujian hipotesis (resampling bootstraping).

\section{Tabel 1. Kriteria Penelitian PLS}

\begin{tabular}{|c|c|}
\hline Kriteria & Penjelasan \\
\hline \multicolumn{2}{|c|}{ Evaluasi Model Struktural } \\
\hline $\begin{array}{l}\mathrm{R}^{2} \text { untuk variabel } \\
\text { laten endogen }\end{array}$ & $\begin{array}{l}\text { Hasil } \mathrm{R}^{2} \text { sebesar } 0.67,0.33 \text { dan } 0.19 \text { untuk variabel laten endogen dalam model } \\
\text { struktural mengindikasikan bahwa model "baik", "moderat", dan "lemah". }\end{array}$ \\
\hline $\begin{array}{l}\text { Estimasi koefisien } \\
\text { jalur }\end{array}$ & $\begin{array}{l}\text { Nilai estimasi untuk hubungan jalur dalam model struktural harus signifikan. } \\
\text { Nilai signifikansi ini dapat diperoleh dengan prosedur bootstrapping. }\end{array}$ \\
\hline $\mathrm{f}^{2}$ untuk effect size & $\begin{array}{l}\text { Nilai } \mathrm{f}^{2} \text { sebesar } 0.02,0.15 \text {, dan } 0.35 \text { dapat diinterpretasikan apakah prediktor } \\
\text { variabel laten mempunyai pengaruh yang lemah, medium atau besar pada tingkat } \\
\text { struktural. }\end{array}$ \\
\hline $\begin{array}{l}\text { Relevansi Prediksi } \\
\left(\mathrm{Q}^{2} \text { dan } \mathrm{q}^{2}\right)\end{array}$ & $\begin{array}{l}\text { Prosedur blindfolding digunakan untuk menghitung } \quad Q^{2}=\frac{\sum D E D}{\sum D O D} \mathrm{D} \text { adalah } \\
\text { omission distance, } \mathrm{E} \text { adalah sum of squares of prediction errors, dan } \mathrm{O} \text { adalah } \\
\text { sum of squares of observation. Nilai } \mathrm{Q}^{2} \text { diatas nol memberikan bukti bahwa } \\
\text { model memiliki predictive relevance. Dalam kaitannya dengan } \mathrm{f}^{2} \text {, dampak relatif } \\
\text { model struktural terhadap pengukuran variabel dependen laten dapat dinilai } \\
\text { dengan : } q^{2}=\frac{\mathrm{Q} 2 \text { included-Q2excluded }}{1-\mathrm{Q} 2 \text { included }}\end{array}$ \\
\hline \multicolumn{2}{|c|}{ Evaluasi Model Pengukuran Refleksif } \\
\hline $\begin{array}{l}\text { Convergent } \\
\text { Validity }\end{array}$ & $\begin{array}{l}\text { Nilai loading faktor harus diatas } 0.70 \text {. Tetapi, untuk tahap awal loading } 0.50 \\
\text { sampai } 0.60 \text { dianggap cukup. }\end{array}$ \\
\hline $\begin{array}{l}\text { Discriminant } \\
\text { Validity }\end{array}$ & $\begin{array}{l}\text { Jika nilai akar dari square root of average variance extracted (AVE) konstruk } \\
\text { lebih besar dari korelasi dengan seluruh konstruk lainnya maka dikatakan } \\
\text { memiliki discriminant validity yang baik. }\end{array}$ \\
\hline $\begin{array}{l}\text { Composite } \\
\text { Realibility }\end{array}$ & $\begin{array}{l}\text { Composite realibility mengukur internal consistency dan nilainya harus diatas } \\
0.70 \text {. }\end{array}$ \\
\hline $\begin{array}{l}\text { Croncbach's } \\
\text { Alpha }\end{array}$ & $\begin{array}{l}\text { Croncbach's alpha dapat memperkuat hasil uji reliabilitas dari hasil composite } \\
\text { reliability sebelumnya. Atau bisa dikatakan bahwa cronbach's alpha untuk } \\
\text { mengevaluasi internal consistency dan nilainya harus diatas } 0.70 \text {. }\end{array}$ \\
\hline \multicolumn{2}{|c|}{ Evaluasi Model Pengukuran Formatif } \\
\hline $\begin{array}{l}\text { Signifikansi nilai } \\
\text { weight }\end{array}$ & $\begin{array}{l}\text { Nilai estimasi untuk model pengukuran formatif harus signifikan. Tingkat } \\
\text { signifikansi ini dinilai dengan prosedur bootstrapping. }\end{array}$ \\
\hline Multikolinieritas & $\begin{array}{l}\text { Variabel manifest dalam blok harus diuji apakah terdapat multikol. Nilai variance } \\
\text { inflation factor (VIF) dapat digunakan untuk menguji hal ini. Nilai VIF diatas } 10 \\
\text { mengindikasikan terdapat multikol. }\end{array}$ \\
\hline
\end{tabular}

Sumber: Chin (1998) dalam Ghozali (2014) 


\section{HASIL PENELITIAN DAN PEMBAHASAN}

Analisis SEM-PLS dilakukan dengan beberapa penilaian diantaranya menilai model pengukuran (outer model) dan model struktural (inner model). Adapun analisis hipotesis yang telah diajukan yaitu mengenai pengaruh iklim psikologis terhadap keinginan karyawan untuk keluar perusahaan melalui kepuasan kerja pada karyawan PT. Hervitama Indonesia.

\subsection{Evaluasi Outer Model}

Tabel 2 menunjukkan bahwa outer loadings dari setiap item pernyataan lebih besar dari 0,50. Ini menunjukkan seluruh indikator pernyataan valid. Sehingga dapat ditarik kesimpulan bahwa variabel-variabel di atas memiliki convergent validity yang baik. Discriminant validity merujuk pada derajat ketidaksesuaian antara atribut-atribut yang seharusnya tidak diukur oleh alat ukur dan konsep-konsep teoritis tentang variabel tersebut.

Tabel 2. Hasil Convergent Validity

\begin{tabular}{cccc}
\hline Variabel & Item & Outer Loadings & Keterangan \\
\hline & X1.1 & 0,582 & Valid \\
& X1.2 & 0,735 & Valid \\
& X1.3 & 0,571 & Valid \\
& X1.4 & 0,531 & Valid \\
& X1.5 & 0,741 & Valid \\
& X1.6 & 0,509 & Valid \\
Iklim Psikologis & X1.7 & 0,615 & Valid \\
& X1.8 & 0,799 & Valid \\
& X1.9 & 0,715 & Valid \\
& X1.10 & 0,627 & Valid \\
& X1.11 & 0,881 & Valid \\
& X1.12 & 0,775 & Valid \\
& X1.13 & 0,634 & Valid \\
& Z1.1 & 0,949 & Valid \\
Kepuasan Kerja & Z1.2 & 0,682 & Valid \\
& Z1.3 & 0,900 & Valid \\
Keinginan & Z1.4 & 0,526 & Valid \\
Karyawan untuk & Y1.1 & 0,682 & Valid \\
Keluar Perusahaan & Y3.2 & 0,921 & Valid \\
\hline
\end{tabular}

Dari Tabel 3 dapat disimpulkan bahwa akar AVE konstruk kepuasan kerja sebesar 0,764 (akar dari 0,583) lebih tinggi daripada korelasi antara konstruk kepuasan kerja dengan kepuasan kerja yang hanya sebesar -0,342. Selain itu akar AVE konstruk keinginan karyawan untuk keluar perusahaan sebesar 0,932 (akar dari 0,868) lebih tinggi daripada korelasi antara konstruk keinginan karyawan untuk keluar perusahaan dengan iklim psikologis yang hanya sebesar 0,672. Begitu juga dengan akar AVE konstruk iklim psikologis sebesar 0,679 (Akar dari 0,461) lebih tinggi daripada korelasi antara konstruk iklim psikologis dengan keinginan karyawan untuk 
keluar perusahaan sebesar -0,672. Jadi semua konstruk dalam model yang diestimasi memenuhi kriteria discriminant validity.

Tabel 3. Discriminant Validity Variabel

\begin{tabular}{cccc}
\hline Variabel & $\begin{array}{c}\text { Iklim } \\
\text { Psikologis }\end{array}$ & $\begin{array}{c}\text { Keinginan Karyawan } \\
\text { untuk Keluar Perusahaan }\end{array}$ & $\begin{array}{c}\text { Kepuasan } \\
\text { Kerja }\end{array}$ \\
\hline $\begin{array}{c}\text { Iklim Psikologis } \\
\text { Keinginan Karyawan }\end{array}$ & 0,679 & & \\
untuk Keluar Perusahaan & $-0,672$ & 0,932 & \\
Kepuasan Kerja & 0,692 & $-0,342$ & 0,764 \\
\hline
\end{tabular}

Tabel 4 menunjukkan bahwa nilai composite reliability untuk semua variabel lebih besar dari 0,70 . Maka dengan demikian model variabel tersebut telah memenuhi composite reliability atau memiliki reliabilitas yang baik.

Tabel 4. Composite Reliability Variabel

\begin{tabular}{cc}
\hline Variabel & Composite Reliability \\
\hline Iklim Psikologis & 0,916 \\
Keinginan Karyawan untuk Keluar Perusahaan & 0,952 \\
Kepuasan Kerja & 0,870 \\
\hline
\end{tabular}

Berdasarkan Tabel 5 menunjukkan bahwa nilai dari cronbach's alpha untuk semua konstruk model berada di atas 0,70 . Dengan demikian model variabel tersebut telah memenuhi cronbach's alpha atau memiliki reliabilitas yang kuat.

Tabel 5. Cronbach's Alpha Variabel

\begin{tabular}{cc}
\hline Variabel & Cronbach's Alpha \\
\hline Iklim Psikologis & 0,899 \\
Keinginan Karyawan untuk Keluar Perusahaan & 0,924 \\
Kepuasan Kerja & 0,823 \\
\hline
\end{tabular}

\subsection{Evaluasi Inner Model}

Hasil analisis $R$ square menunjukkan model pengaruh iklim psikologis terhadap keinginan karyawan untuk keluar perusahaan memberikan nilai $r$-square sebesar 0,480 dan bisa di interpretasikan bahwasannya variabel konstruk keinginan karyawan untuk keluar perusahaan dapat dijelaskan oleh variabel iklim psikologis sebesar $48 \%$ dan variabel-variabel lain yang tidak terdapat dalam penelitian mampu dijelaskan sebesar 54\%. Model pengaruh iklim psikologis terhadap kepuasan kerja memberikan nilai $r$-square sebesar 0,478 dan dapat di interpretasikan bahwasannya variabel konstruk kepuasan kerja dapat dijelaskan oleh variabel iklim psikologis sebesar 47,8\% sedangkan variabel lain yang tidak terdapat dalam penelitian ini sebesar 52,2\%. 
Hasil perhitungan nilai $q$-square predictive relevance pada model penelitian ini sebesar 0,77056 dimana nilai tersebut lebih besar dari nol. Itu menunjukkan bahwa model memiliki predictive relevance yang dapat menjelaskan model sebesar $77 \%$.

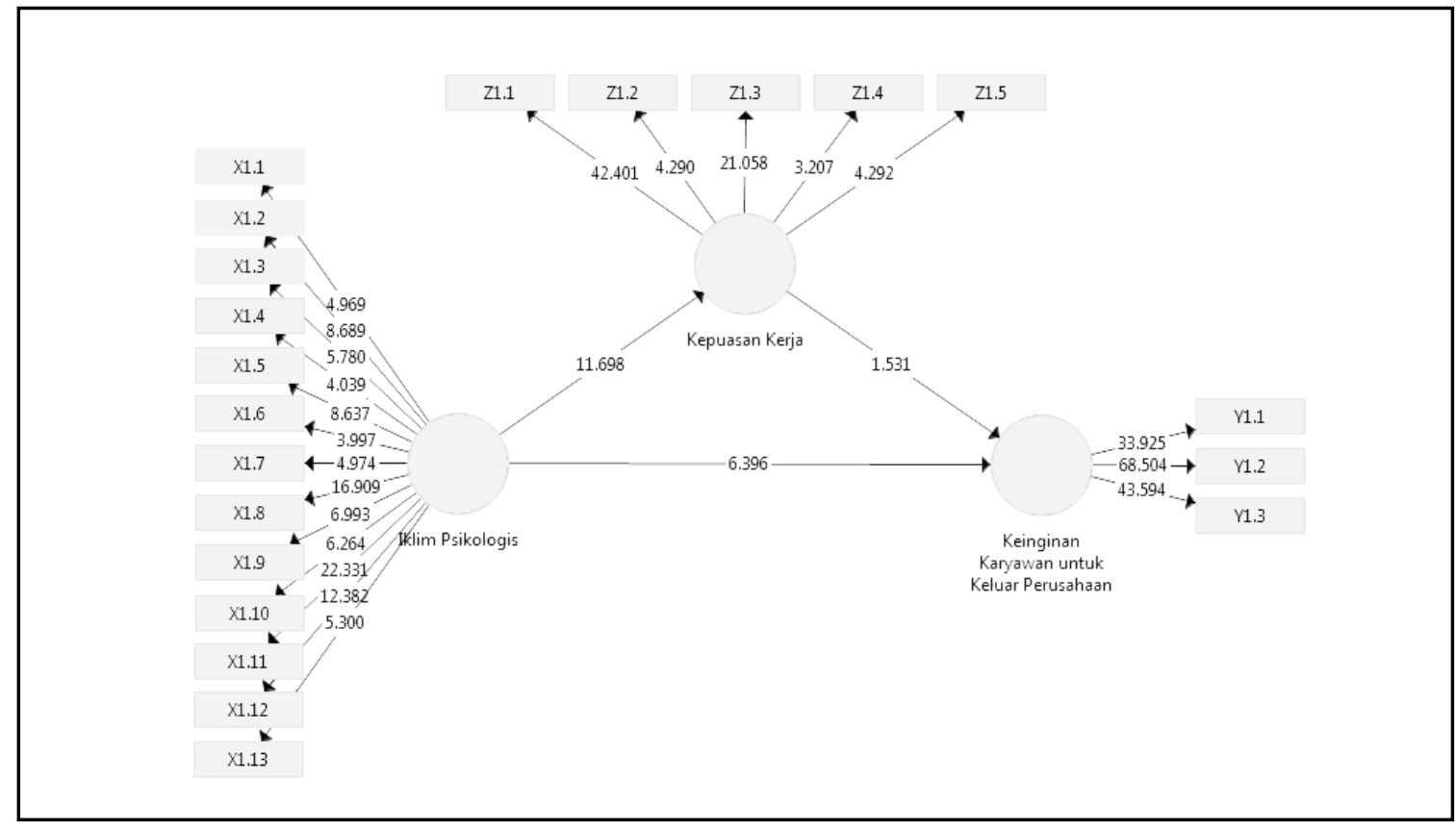

\section{Gambar 3. Uji Measurement Boostraping Model}

Berdasarkan uji measurement bootstraping model pada Gambar 3 maka dapat dilihat inner model dari ketiga variabel. Inner model digunakan untuk melihat hubungan antar konstruk dan nilai signifikansi pada tabel path coefficients.

Besarnya nilai $t$-statistics pengaruh iklim psikologis terhadap keinginan karyawan untuk keluar perusahaan sebesar 6,396 > 1,96. Ini menunjukkan bahwa adanya pengaruh yang signifikan pada variabel iklim psikologis terhadap keinginan karyawan untuk keluar perusahaan. Sedangkan nilai koefisien estimate sebesar $-0,834$. Koefisien tersebut memiliki tanda negatif yang artinya apabila semakin baik tingkat iklim psikologis maka keinginan karyawan untuk keluar perusahaan semakin turun, begitupun sebaliknya. Makna positif menggambarkan berbanding terbalik.

Adapun besarnya nilai $t$-statistics pengaruh iklim psikologis terhadap kepuasan kerja sebesar 11,698 > 1,96. Ini menujukkan terdapat pengaruh yang signifikan pada variabel iklim psikologis terhadap kepuasan kerja. Sedangkan nilai koefisien estimate yaitu sebesar 0,692. Koefisien tersebut memiliki tanda positif yang artinya apabila semakin baik tingkat iklim psikologis maka kepuasan kerja juga semakin baik pula, begitupun sebaliknya. Makna tanda positif menggambarkan berbanding lurus.

Selanjutnya besarnya nilai $t$-statistics pengaruh kepuasan kerja terhadap keinginan karyawan untuk keluar perusahaan sebesar 1,531 < 1,96. Ini menunjukkan terdapat pengaruh yang tidak signifikan pada variabel kepuasan kerja terhadap keingian karyawan untuk keluar perusahaan. Sedangkan koefisien estimate sebesar 0,234, koefisien tersebut memiliki tanda 
positif yang artinya apabila semakin tinggi tingkat kepuasan kerja maka keinginan karyawan untuk keluar perusahaan juga semakin tinggi pula. Makna tanda positif menggambarkan berbanding lurus.

Tabel 6. Hasil Path Coefficents

\begin{tabular}{lcccc}
\hline \multicolumn{1}{c}{ Hubungan Antar Variabel } & $\begin{array}{c}\text { Original } \\
\text { Sample }\end{array}$ & T-Statistics & Keterangan & Kesimpulan \\
\hline $\begin{array}{l}\text { Iklim Psikologis } \rightarrow \\
\begin{array}{l}\text { Keinginan Karyawan } \\
\text { untuk Keluar Perusahaan }\end{array}\end{array}$ & $-0,834$ & 6,396 & $\begin{array}{c}\geq 1,96 \\
\text { (Signifikan) }\end{array}$ & $\begin{array}{c}\text { Hipotesis } \\
\text { Diterima }\end{array}$ \\
$\begin{array}{l}\text { Iklim Psikologis } \rightarrow \\
\text { Kepuasan Kerja }\end{array}$ & 0,692 & 11,698 & $\begin{array}{c}\geq 1,96 \\
\text { (Signifikan) }\end{array}$ & $\begin{array}{c}\text { Hipotesis } \\
\text { Diterima }\end{array}$ \\
$\begin{array}{l}\text { Kepuasan Kerja } \rightarrow \\
\text { Keinginan Karyawan } \\
\text { untuk Keluar Perusahaan }\end{array}$ & 0,234 & 1,531 & $\begin{array}{c}\geq 1,96 \\
\text { (Tidak }\end{array}$ & $\begin{array}{c}\text { Hipotesis } \\
\text { Signifikan) }\end{array}$ \\
\hline
\end{tabular}

Tabel 7 menunjukan besarnya koefisien pengaruh langsung iklim psikologis terhadap keinginan karyawan untuk keluar perusahaan yaitu sebesar - 0,834 dan nilai signifikan pada $5 \%$ (nilai $\mathrm{t}$ hitung $>\mathrm{t}$ tabel 1,96). Adapun pengaruh tidak langsung iklim psikologis terhadap keinginan karyawan untuk keluar perusahaan melalui kepuasan kerja yaitu 0,162 dan signifikan pada $5 \%$ (nilai t hitung $>\mathrm{t}$ tabel 1,96 ).

Tabel 7. Pengaruh Langsung dan Tidak Langsung

\begin{tabular}{lcc}
\hline \multicolumn{1}{c}{ Path } & Koefisien Langsung & Kesimpulan \\
\hline $\begin{array}{l}\text { Iklim Psikologis } \rightarrow \\
\text { Keinginan Karyawan untuk Keluar Perusahaan }\end{array}$ & $-0,834$ & Hipotesis \\
$\begin{array}{l}\text { Diterima } \\
\text { Iklim Psikologis } \rightarrow \text { Kepuasan Kerja } \rightarrow\end{array}$ & & Hipotesis \\
Keinginan Karyawan untuk Keluar Perusahaan & 0,162 & Diterima \\
\hline
\end{tabular}

Dapat disimpulkan bahwa iklim psikologis berpengaruh secara langsung terhadap keinginan karyawan untuk keluar perusahaan dan dapat berpengaruh secara tidak langsung terhadap keinginan karyawan untuk keluar perusahaan melalui kepuasan kerja. Besarnya koefisien pengaruh langsung serta tidak langsung dapat dihitung sebagai berikut:

Direct Effect : iklim psikologis $\rightarrow$ keinginan karyawan untuk keluar perusahaan $=-0,834$

Indirect Effect : iklim psikologis $\rightarrow$ kepuasan kerja $\rightarrow$ keinginan karyawan untuk keluar perusahaan $=(0,692) \times(0,234)=0,162$

Berdasarkan hasil perhitungan diatas dapat diketahui bahwa pengaruh secara tidak langsung lebih besar daripada pengaruh secara langsung. 


\subsection{Pengaruh Iklim Psikologis Terhadap Keinginan Karyawan untuk Keluar Perusahaan}

Dari hasil pengujian dapat diketahui bahwa iklim psikologis berpengaruh negatif dan signifikan terhadap keinginan karyawan untuk keluar perusahaan. Ini dapat diketahui dari data nilai t-statistic bernilai 6,396 yaitu lebih besar dari 1,96 sehingga $\mathrm{H}_{1}$ diterima.

Hasil penelitian ini memperkuat penelitian yang dilakukan oleh Garner dan Hunter (2013) yang menyatakan bahwa iklim psikologis berpengaruh secara negatif dan signifikan terhadap keinginan karyawan untuk keluar perusahaan. Penelitian tersebut menggunakan variabel iklim psikologis, sikap kerja, dan keinginan karyawan untuk keluar perusahaan.

Berdasarkan hasil penelitian jika terdapat pengaruh negatif dan signifikan maka dapat dijelaskan semakin baik iklim psikologis yang ada di PT. Hervitama Indonesia maka keinginan karyawan untuk keluar perusahaan akan menurun. Berdasarkan hasil estimasi inner model menggunakan software smartPLS diketahui bahwa pengaruh iklim psikologis terhadap keinginan karyawan untuk keluar perusahaan PT. Hervitama Indonesia memiliki koefisien estimate bertanda negatif yaitu sebesar $-0,834$. Hasil tersebut dapat disimpulkan bahwa iklim psikologis memiliki pengaruh yang besar terhadap keinginan karyawan untuk keluar perusahaan di PT. Hervitama Indonesia.

Melalui hasil wawancara dengan salah satu karyawan menjelaskan bahwa beberapa karyawan yang merasa kesulitan dalam melakukan pekerjaannya kebanyakan mereka akan meminta bantuan kepada rekan kerjanya. Sehingga mereka beranggapan bahwa rekan kerja yang ada dilingkungan perusahaan dirasa mendukung untuk membantu menyelesaikan masalah yang dihadapinya. Atau dengan mereka senantiasa berusaha sendiri untuk menyelesaikan pekerjaan mereka sehingga pekerjaan yang dianggap tidak dapat terselesaikan dapat teratasi dengan baik. Dengan apa yang dikerjakan tersebut mereka merasa puas dengan apa yang telah mereka kerjakan dan dengan tunjangan ataupun gaji yang telah sesuai dengan apa yang telah mereka kerjakan. Sehingga tidak memungkiri bahwa bonus untuk hasil kinerja yang baik biasa didapatkan oleh karyawan, baik itu berupa uang ataupun barang lainnya. Sehingga dengan adanya hal tersebut karyawan akan termotivasi untuk bekerja lebih baik lagi.

Hasil analisis deskriptif jawaban responden untuk variabel iklim psikologis dalam kategori tinggi jika dilihat pada katagori three box method, yaitu dengan nilai rata-rata variabel iklim psikologis sebesar 3,99 dan hasil statistik nilai rata-rata variabel keinginan karyawan untuk keluar perusahaan sebesar 2,28. Iklim psikologis mampu menjelaskan keinginan karyawan untuk keluar perusahaan dapat dilihat dari segi otonomi dan kehangatan yang terjadi di lingkungan perusahaan.

Nilai paling tinggi terjadi di indikator otonomi dan kehangatan, bahwa otonomi yang terjadi di perusahaan dimana karyawan dapat menyelesaikan pekerjaan yang mereka lakukan tetapi tetapi tetap sesuai dengan job desk perusahaan yang telah ditetapkan dan kehangatan yang terjadi di perusahaan juga terjadi sangat baik sehingga lingkungan di perusahaan juga terjadi baik pula. Sehingga secara langsung kualitas dan kuantitas karyawan dapat diketahui dengan baik dan hal tersebut akan bermanfaat bagi kemajuan perusahaan.

Mendukung penelitian Yee, et al., (2014), karyawan dengan iklim psikologis (individu) yang baik mampu memobilisasi potensi kreatif ke hasil yang kreatif. Hal tersebut dapat semakin kuat potensi kreatifnya saat adanya dukungan dan kebebasan berekspresi sehingga akhirnya 
berdampak kepada peningkatan kinerja karyawan. Berdasarkan analisis diatas dapat diketahui bahwa iklim psikologis mampu mempengaruhi keinginan karyawan untuk keluar perusahaan pada PT. Hervitama Indonesia. Semakin karyawan merasa baik dan nyaman terhadap iklim psikologis yang ada di perusahaan dengan mampu menurunkan keinginan karyawan untuk keluar perusahaan di perusahaan tersebut.

Berdasarkan hasil wawancara dengan salah satu bagian SDM di PT. Hervitama Indonesia, beliau menyampaikan bahwa ada beberapa pernyataan yang didapatkan dari beberapa karyawan, yaitu: keinginan karyawan untuk mencari pekerjaan yang lebih baik lagi dari yang mereka dapatkan saat ini, ada yang menyatakan bahwa mereka bekerja hanya untuk mencari pengalaman dan mencari pengalaman baru dibidang lainnya, dan tuntutan ekonomi yang tinggi dengan adanya tunjangan keluarga yang banyak sehingga gaji yang diberikan perusahaan dirasa kurang dan tidak cukup untuk memenuhi kebutuhan sehari-hari. Sehingga keinginan karyawan untuk keluar perusahaan tidak mempengaruhi karyawan untuk keluar perusahaan.

\subsection{Pengaruh Iklim Psikologis terhadap Kepuasan Kerja}

Dari hasil pengujian dapat diketahui bahwa iklim psikologis berpengaruh positif dan signifikan terhadap kepuasan kerja. Ini dapat dilihat dari data nilai t-statistic bernilai 11,698 yaitu lebih besar dari 1,96 sehingga $\mathrm{H}_{2}$ diterima.

Hasil penelitian ini memperkuat penelitian yang dilakukan Tenaya dan Suwandana (2019) bahwa iklim psikologis berpengaruh positif signifikan terhadap kepuasan kerja. Penelitian tersebut menggunakan variabel iklim psikologis, kepuasan kerja dan OCB.

Berdasarkan hasil penelitian jika terdapat pengaruh positif dan signifikan maka dapat dijelaskan semakin baik iklim psikologis yang ada di PT. Hervitama Indonesia maka kepuasan kerja karyawan akan semakin baik pula. Berdasarkan hasil estimasi inner model menggunakan software smartPLS diketahui bahwa iklim psikologis terhadap kepuasan kerja karyawan PT. Hervitama Indonesia memiliki koefisien estimate bertanda positif yaitu sebesar 0,692. Hasil tersebut dapat disimpulkan bahwa iklim psikologis memiliki pengaruh yang besar terhadap kepuasan kerja karyawan PT. Hervitama Indonesia.

Jika tanggapan yang diberikan atasan terhadap karyawan semakin baik serta memberikan pengakuan atas keberadaannya, memotivasi semua yang yang dikerjakan karyawan, mengarahkan karyawan untuk menunjukkan kemampuan diri dan perasaan yang dirasakan di tempat kerja dan lingkungan yang ada disekitarnya sampai dengan menghargai kontribusi yang telah diberikan karyawan terhadap perusahaan maka dengan hal tersebut kepuasan kerja yang dirasakan oleh karyawan juga semakin baik pula.

Melalui hasil wawancara dengan salah satu karyawan mengatakan bahwa beliau puas bekerja di perusahaan ini. Beliau puas dari beberapa segi, salah satunya adalah dari sikap atasan terhadap bawahannya. Mulai dari cara atasan memberi motivasi atau dukungan terhadap karyawan, mendukung semua ide yang disampaikan atau ditawarkan oleh karyawan baik itu dalam menyelesaikan pekerjaan karyawan secara individu ataupun untuk keseluruhan kemajuan perusahaan, selalu memberikan arahan jika karyawan merasa apa yang telah dikerjakan dirasa kurang tepat atau belum maksimal dan selalu meminta saran tentang kekurangan dan saran kepada karyawan untuk kemajuan perusahaan. 
Hasil analisis deskriptif jawaban responden untuk variabel iklim psikologis berkategori tinggi jika dilihat pada katagori three box method, yaitu dengan rata-rata variabel iklim psikologis sebesar 3,99 dan hasil statistik nilai rata-rata variabel kepuasan kerja sebesar 3,91. Iklim psikologis mampu menjelaskan dari otonomi di perusahaan, tantangan yang diberikan dalam pekerjaan, pengakuan dari atasan, ambiguitas pekerjaan yang terjadi di perusahaan, tekanan yang terjadi, kelebihan beban, dukungan atasan terhadap karyawan, kerjasama tim, kehangatan yang ada di perusahaan, inovasi yang diberikan, kesadaran manajemen, keterbukaan, kontribusi dalam kepuasan kerja yang terjadi di perusahaan.

Mendukung dari penelitian Biswas dan Varma (2011), yaitu iklim psikologis memberikan dampak yang baik untuk meningkatkan rasa kepuasan kerja pada setiap diri karyawan. Hasil analisis diatas dapat diketahui bahwa atasan berhasil menciptakan iklim psikologis yang baik yang memiliki dampak pada tingkat kepuasan kerja karyawan PT. Hervitama Indonesia.

\subsection{Pengaruh Kepuasan Kerja terhadap Keinginan Karyawan untuk Keluar Perusahaan}

Dari hasil pengujian dapat diketahui bahwa kepuasan kerja tidak memberikan pengaruh yang signifikan terhadap keinginan karyawan untuk keluar perusahaan. Ini dapat diketahui dari data nilai t-statistic bernilai 1,531 yaitu kurang dari 1,96 sehingga $\mathrm{H}_{3}$ ditolak.

Hasil penelitian ini juga memperkuat penelitian yang dilakukan Witasari (2009); Gilad, et al., (2011) yang menunjukkan bahwa dalam penelitian tersebut ditemukan bahwa tidak ada pengaruh antara hubungan kepuasan kerja terhadap keinginan karyawan untuk keluar perusahaan.

Berdasarkan hasil penelitian jika terdapat hubungan yang tidak berpengaruh maka dapat dijelaskan jika tinggi rendahnya kepuasan kerja karyawan hal tersebut tidak akan mempengaruhi tinggi atau rendahnya keinginan karyawan untuk keluar perusahaan di PT. Hervitama Indonesia. Berdasarkan hasil estimasi inner model menggunakan software smartPLS diketahui bahwa iklim psikologis terhadap keinginan karyawan untuk keluar perusahaan di PT. Hervitama Indonesia memiliki koefisien estimate bertanda positif yaitu sebesar 0,234. Hasil tersebut dapat disimpulkan bahwa walaupun nilai kepuasan kerja karyawan memiliki koefisien estimate bertanda positif hal tersebut tidak memiliki pengaruh terhadap keinginan karyawan untuk keluar perusahaan di PT. Hervitama Indonesia.

Peningkatan kepuasan kerja dalam diri karyawan PT. Hervitama Indonesia dapat dilihat dari beberapa indikator diantaranya dapat dilihat dari pekerjaan itu sendiri, gaji, kesempatan promosi yang diberikan oleh perusahaan, pengawasan yang dilakukan dengan baik, dan rekan kerja yang mendukung. Adanya hal tersebut, tidak mempengaruhi keinginan karyawan untuk keluar perusahaan. Sehingga meskipun gaji yang mereka terima besar dan mereka merasa puas dengan gaji yang mereka terima tetapi adanya hal tersebut tidak membuat karyawan akan tetap bertahan di perusahaan tersebut dan begitupula sebaliknya

Dari hasil wawancara dengan salah satu karyawan menjelaskan bahwa rekan kerja yang ada dilingkungan perusahaan sangat terbuka dalam hal pekerjaan baik itu meminta bantuan ataupun saran, tidak hanya itu saja pengawasan dari segi memberikan kebebasan pada karyawan untuk mengambil kepusan dalam mengerjakan pekerjaan mereka sendiri juga baik. Tetapi hal 
tersebut tidak dapat digunakan untuk ukuran bahwa karyawan yang bekerja di lingkungan PT. Hervitama Indonesia tidak akan meninggalkan perusahaan.

Hasil analisis deskriptif jawaban responden untuk variabel kepuasan kerja dalam kategori tinggi jika dilihat pada katagori three box method, yaitu dengan rata-rata variabel kepuasan kerja sebesar 3,91 dan hasil statistik nilai rata-rata variabel keinginan karyawan untuk keluar perusahaan sebesar 2,28. Kepuasan kerja tidak mampu untuk dapat meningkatkan ataupun mengurangi keinginan karyawan untuk keluar perusahaan. Baik itu kepusan kerja dilihat dari pekerjaan itu sendiri, pengawasan yang diberikan atasan, gaji yang diberikan, kesempatan promosi, dan rekan kerja yang ada dilingkungan perusahaan.

\subsection{Pengaruh Iklim Psikologis terhadap Keinginan Karyawan untuk Keluar Perusahaan melalui Kepuasan Kerja}

Hasil pengujian hipotesis, menunjukkan bahwa kepuasan kerja tidak mengintervening secara penuh pengaruh antara iklim psikologis terhadap keinginan karyawan untuk keluar perusahaan sehingga $\mathrm{H}_{4}$ ditolak. Besarnya $t$-statistic $>1,96$ dan pengaruh tidak langsung nilai koefisien yaitu 0,162 , sedangkan pengaruh langsung yaitu $-0,834$. Ini menunjukkan bahwa kepuasan kerja berperan rendah dalam mempengaruhi keinginan karyawan untuk keluar perusahaan.

Jika dikaitkan pada PT. Hervitama Indonesia dengan didukung melalui wawancara bahwa karyawan mempunyai iklim psikologis yang baik dalam beberapa hal, salah satunya adalah dari segi menyelesaikan pekerjaan. Karyawan mampu menyelesaikan pekerjaannya sendiri dengan cara mereka sendiri dan dengan baik, melakukan semua pekerjaan yang dianggap mereka baru dan bukan yang biasanya mereka kerjakan tetapi dapat menyelesaikan dengan baik. Selain itu karyawan mempunyai kepercayaan diri untuk menghasilkan ide-ide kreatif, memecahkan masalah dan mencoba ide-ide baru. Berdasarkan analisis diatas dapat diketahui jika karyawan mempunyai kepuasan kerja cukup bagus dan nanti akan berdampak pada keinginan karyawan untuk keluar perusahaan.

Analisis penelitian ini mampu memberikan informasi bahwa apabila kepuasan kerja karyawan dalam perusahaan baik maka akan membuat iklim psikologis terhadap keinginan karyawan untuk keluar perusahaan berpengaruh signifikan positif.

\section{SIMPULAN}

Kesimpulan dari hasil penelitian ini yaitu: (1) Iklim psikologis berpengaruh negatif dan signifikan terhadap keinginan karyawan untuk keluar perusahaan pada PT. Hervitama Indonesia. (2) Iklim psikologis berpengaruh positif dan signifikan terhadap kepuasan kerja pada PT. Hervitama Indonesia. (3) Kepuasan kerja tidak memberikan pengaruh yang signifikan terhadap keinginan karyawan untuk keluar perusahaan pada PT. Herviatama Indonesia. (4) Iklim psikologis tidak mengintervening keinginan karyawan untuk keluar perusahaan melalui kepuasan kerja pada PT. Hervitama Indonesia.

Saran untuk meningkatkan iklim psikologis yaitu perlunya pemimpin melakukan peningkatan kualitas dan kuantitas dalam hal dukungan yang diberikan kepada karyawan atau 
bawahan dapat dilakukan dengan cara melakukan bimbingan pada karyawan dalam melakukan pekerjaan yang baik.

\section{DAFTAR PUSTAKA}

Andini, R. (2006). Analisis Pengaruh Kepuasan Gaji, Kepuasan Kerja, Komitmen Organisasional terhadap Turnover Intention Studi Kasus pada Rumah Sakit Roemani Muhammadiyah Semarang. Diponegoro.

Aslani, F., \& Fayyazi, M. (2015). The Impact of Work-Life Balance on Employees' Job Satisfaction and Turnover Intention: The Moderating Role of Continuance Commitment. International Letters of Social and Humanistic Sciences, 51, 33-41. https://doi.org/10.18052/www.scipress.com/ILSHS.51.33

Biswas, S., \& Varma, A. (2011). Antecendents of Employee Performance: An Empirical Investigation in India Employee Relation, 34(2), 177-192.

Carless, S. A. (2004). Does Psychological Empowerment Mediate the Relationship Between Psychological Climate and Job Satisfaction? Journal of Business and Psychology, 18(4), 405.

Chen, G., Ployhart, R. E., Thomas, H. C., Anderson, N., \& Bliese, P. D. (2011). The Power of Momentum: A New Model of Dynamic Relationships Between Job Satisfaction Change and Turnover Intentions. Academy of Management Journal, 54(1), 159-181.

Data Internal PT. Hervitama Indonesia, (2017). Sidoarjo, Jawa Timur, Indonesia.

Garner, B. R., \& Hunter, B. D. (2013). Examining the temporal relationship between psychological climate, work attitude, and staff turnover. Journal of Substance Abuse Treatment, 44(2), 193-200. https://doi.org/10.1016/j.jsat.2012.05.002

Ghozali, I. (2008). Structural Equation Modeling: Metode Alternatif dengan Partial Least Square (PLS). Semarang: Badan Penerbit Universitas Diponegoro.

Ghozali, I. (2014). Structural Equation Modeling: Metode Alternatif dengan Partial Least Square (PLS). Semarang: Badan Penerbit Universitas Diponegoro.

Gim, G., Desa, N. M., \& Ramayah, T. (2015). Competitive Psychological Climate and Turnover Intention with the Mediating Role of Affective Commitment. Procedia - Social and Behavioral Sciences, 172, 658-665. https://doi.org/10.1016/j.sbspro.2015.01.416

Gyensare, M. A., Kumedzro, L. E., Sanda, A., \& Boso, N. (2017). Linking Transformational Leadership to Turnover Intention in the Public Sector: The Influences of Engagement, Affective Commitment and Psychological Climate. African Journal of Economic and Management Studies. Retrieved from https://doi.org/10.1108/AJEMS-07-2016-0099

Hakim, R. F., \& Surjanti, J. (2018). Pengaruh Iklim Psikologis terhadap Kinerja Karyawan dengan kepuasan Kerja sebagai Variabel Intervening pada PT. Bank Jatim Cabang Syariah Surabaya. Ilmu Manajemen, 6(2).

Hanafiah, M. (2014). Pengaruh Kepuasan Kerja dan Ketidakamanan Kerja (Job Insecurity) dengan Intensi Pindah Kerja (Turnover Intention) ada Karyawan PT. Buma Desa Suara Kecamatan Sambaliung Kabupaten Berau. E Journal PsIKOLOGI, 1(3), 303-312.

Handoko, H. (1998). Manajemen Personalia dan Sumber Daya Manusia. Yogyakarta: BPFE. 
Huang, S., Chen, Z., Liu, H., \& Zhou, L. (2016). Job Satisfaction and Turnover Intention in China: The Moderating Effects of Job Alternatives and Policy Support. Chinese Management Studies. https://doi.org/10.1108/CMS-12-2016-0263 Permanent

Isaksen, S. G., \& Lauer, K. J. (1999). Relationship Between Cognitive Style And Individual Psychological Climate: Reflecions on A Previous Study. Studia Psychologica, 41(3), 177189.

James, L. R., Choi, C. C., Ko, C.-H. E., K., P. M., Minton, M. K., Wright, M. A., \& Kim, K.-I. (2008). Organizational and Psychological Climate: A Review of Theory and Research. European Journal of Work and Organizational Psychology, 17(1), 5-23.

James, L. R., \& Sells, S. B. (1981). Psychological Climate: Theoretical Perspectives and Empirical Research. In D. Magnusson (Toward a P, pp. 276-295). Hillsdale: NJ: Erlbaum.

Javed, M., Yasir, M., Khan, M. A., \& Aamir, S. (2014). Effect of Role Conflict, Work Life Balance and Job Stress on Turnover Intention: Evidence from Pakistan. Journal of Basic and Applied Scientific Research, 4(3), 125-133.

Jones, A. P., \& Jamest, L. R. (1979). Psychological Climate: Dimensions and Relationships of Individual and Aggregated Work Environment Perceptions. Organizational Behavior and Human Performance, 23, 201-250.

Karanika-Murray, M., \& Michaelides, G. (2015). Workplace Design: Conceptualizing and Measuring Workplace Characteristics for Motivation. Journal of Organizational Effectiveness: People and Performance, 2(3), 1-22.

Karanika-Murray, M., Michaelides, G., \& Wood, S. J. (2017). Job Demands, Job Control, Psychological Climate, and Job Satisfaction: A Cognitive Dissonance Perspective. Journal of Organizational Effectiveness, 4(3), 238-255. https://doi.org/10.1108/JOEPP-02-20170012

Lambert, E. G., Hogan, N. L., \& Barton, S. M. (2001). The Impact of Job Satisfaction on Turnover Intent: A Test of a Structural Measurement Model Using a National Sample of Workers. The Social Science Journal, 38, 233-250.

Lestari, S. (2015). Pengelolaan Diversitas Karyawan dalam Membangun Keunggulan Kompetitif. Jurnal Fokus Bisnis, 14(01), 1-7.

Luthans, F. (2005). Organizational Behavior (Seventh Ed). New York: Mc Graw-Hill, Inc.

Luthans, F. (2006). Perilaku Organisasi (Edisi Sepu). Yogyakarta: PT. Andi.

Madera, J. M., Dawson, M., \& Guchait, P. (2016). Psychological Diversity Climate: Justice, Racioethnic Minority Status, and Job Satisfaction. International Journal of Contemporary Hospitality Management. https://doi.org/http://dx.doi.org/10.1108/IJCHM-06-2015-0304

Mangkunegara, A. A. A. P. (2011). Manajemen Sumber Daya Manusia Perusahaan. Bandung.

Mansur, A. (2018). Gencar Pembangunan, Potensi Bisnis Desain dan Interior Kian Mentereng. Retrieved from http://www.neraca.co.id/article/103516/gencar-pembangunan-potensibisnis-desain-dan-interior-kian-mentereng

Maranggi, N. M. V. P., \& Subudi, M. (2018). Pengaruh Iklim Psikologis terhadap Kepuasan Kerja dan Organizational Citizenship Behaviour (OCB), 780-794.

Mathis, Robert, L., \& Jackson, J. H. (2011). Human Resource Management (Edisi Sepuluh). Jakarta: Salemba Empat. 
Mathis, R. L., \& Jackson, J. H. (2001). Manajemen Sumber Daya Manusia (Jilid 1). Jakarta: Salemba Empat.

Mianto, A., Hendriani, S., \& Efni, Y. (2018). Pengaruh Motivasi dan Iklim Psikologis terhadap Kinerja Pegawai pada Kantor Pelayanan Pajak Madya Pekanbaru dengan Kepuasan Kerja sebagai Variabel Intervening. Tepak Manajemen Bisnis, X(3), 425-444.

Munyaka, S. A. (2012). The Relationship Between Authentic Leadership, Psychological Climate, Team Commitment and the Intention to Quit in a South African Manufacturing Organisation. Nelson Mandela Metropolitan University.

Munyaka, S. A., Boshoff, A., Pietersen, J., \& Snelgar, R. (2017). The Relationship Between Authentc Leadership, Psychological Capital, Psychological Climate, Team Commitment and Intention to Quit. SA Journal of Industrial Psychology/SA Tydskrif Vir Bedryfsielkunde 430, 1430. Retrieved from https://doi.org/10.4102/sajip.v43i0.1430

Nafiudin. (2015). Pengaruh Work Life Balance dan Kepuasan Kerja terhadap Turnover Intention Karyawan pada PT Bank Agroniaga Tbk Cabang Bandung. Jurnal Sains Manajemen, 1(1), 24-38.

Nayaputera, Y. (2011). Analisis Pengaruh Kepuasan Kerja dan Stres Kerja terhadap Intensi Turnover Customer Service Employee di PT. Plaza Indonesia Realty Tbk. Universitas Indonesia.

Oluwafemi, O. J. (2013). Predictors of Turnover Intention Among Employees in Nigeria' S Oil Industry. Organizations and Markert in Emerging Economies, (4(2)), 42-63.

Rachmawati, A. N. (2018). Permintaan Jasa Desain Interior masih Tumbuh Cukup Signifikan. Retrieved from http://jatim.tribunnews.com/2018/03/26/permintaan-jasa-desain-interior-dijawa-timur-masih-tumbuh-cukupsignifikan

Radjasa, S. (2015). Mercer Talent Consulting \& Information Solution. Retrieved from https://swa.co.id/swa/trends/management/turnovertalent-tinggi-ini-dia-pemicunyasurvei\%0ARahadjeng, A. (2016). Pengaruh Perceived

Robbins, S. P. (2001). Perilaku Organisasi: Konsep, Kontroversi, Aplikasi (Jilid 1 Ed). Jakarta: Prenhallindo.

Schneider, B., \& Snyder, R. A. (1975). Some Relationships Between Job Satisfaction and Organizational Climate. Journal of Applied Psychology, 60, 318-328.

Soeselo. (2017). Pengaruh Keadilan Distributif dan Prosedural Kompensasi terhadap Kepuasan Kerja dan Kinerja Perawat, 6(1), 18-26.

Suifan, T. S., Diab, H., \& Abdallah, A. B. (2017). Does Organizational Justice Affect TurnoverIntention in a Developing Country? The Mediating Role of Job Satisfaction and Organizational Commitment. Journal of Management Development, 36(9), 1137-1148. https://doi.org/10.1108/JMD-02-2017-0048

Swift, C. O., \& Campbell, C. (2016). Psychological Climate: Relevance for Sales Managers and Impact on Consequent Job Satisfaction. Journal of Marketing Theory and Practice, 6679(March). https://doi.org/10.1080/10696679.1998.11501786

Tenaya, I. G. I., \& Suwandana, I. G. M. (2019). Pengaruh Iklim Psikologis terhadap Keouasan Kerja dan Organizational Citizenship Behavior di PT. Sarana Tani Pratama. E-Jurnal Manajemen Unud, 8(1), 7253-7282. 
Tnay, E., Othman, A. E. A., Siong, H. C., \& Lim, S. L. O. (2013). The Influences of Job Satisfaction and Organizational Commitment on Turnover Intention. Procedia - Social and Behavioral Sciences, 97, 201-208. https://doi.org/10.1016/j.sbspro.2013.10.223

Wahyuni, A. S., Zaika, Y., \& Anwar, R. (2014). Analisis Faktor-Faktor yang Mempengaruhi Turnover Ontention (Keinginan Berpindah) Karyawan pada Perusahaan Jasa Kontruksi. Jurnal Rekayasa Sipil, 8(2), 89-95.

Witasari, L. (2009). Analisis Pengaruh Kepuasan Kerja dan Komitmen Organisasi terhadap Turnover Intentions (Studi Empiris pada Novotel Semarang). Universitas Diponegoro.

Yee, W. F., Pink, L. S., \& Sern, M. L. C. (2014). The Effect of a Psychological Climate for Creativity on Job Satisfaction and Work Performance. International Journal of Economics and Management, 8(Specialissue), 97-116. 